\title{
Evaluation of adapted books and the use of Tactile Cartography at public schools in the State of São Paulo, Brazil
}

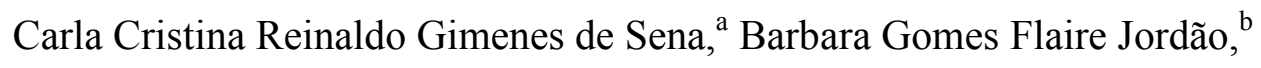 \\ a Universidade Estadual Paulista “Julio de Mesquita Filho”. Ourinhos, São Paulo, Brazil; carla@ourinhos.unesp.br \\ ${ }^{b}$ São Paulo, Brazil, barbaraflaire@hotmail.com
}

\begin{abstract}
Brazil adopts an educational inclusion policy, which is based on the insertion of students with special needs in the elementary and high school. In the State of São Paulo, Brazil, visually impaired students, who attend public schools, receive books adapted for blind and low sighted individuals, so they can participate on Geography classes. This paper presents the results of the analysis of the enlarged material adapted to braille used at the elementary school. The analysis was based on the principle of the graphical semiology developed by ALMEIDA (2015), which discusses the use of alternative materials in order to represent areas, lines and dots with different heights, textures and shapes. The results were obtained through interviews, surveys and evaluation of teachers and students, who somehow experience the specificities of the visually impaired students daily. We observed that the adapted books do not bring all information contained in the original versions of the books and some of the exercises are not presented. Furthermore we could notice that the teachers and other students do not have any level of proficiency in understanding braille, which can hamper the interaction between visually impaired and the other students. After the observations, we adapted 22 maps using colored materials and handcraft techniques taking in-to account the different needs of the low sighted audience. The materials used are easy to be found and purchased, since they have a low cost. Using this alternative material we achieved a learning that was representative to all students and to the teachers, providing the socialization of the acquired knowledge.
\end{abstract}

Keywords: Tactile Cartography, visually impaired students, Geography teaching

\section{Introduction}

Any analysis that pervades themes which involve power, inequality and society must take education in consideration. It is the foundation of social life and it is responsible for the permanence or the shifting of system invigor. By questioning the conflicting material available to visually impaired students at the public schools of the State of São Paulo, Brazil, it is necessary to understand how the process of educational inclusion has developed in the country and how was this material chosen to be used as a supplement to the textbook.

In 1994, when Brazil signed the Declaration of Salamanca (Spain), which proclaimed the rights to people with special needs to receive proper education based on a pedagogy that is centered in the student, an inclusive teaching became mandatory in the country and has created several discussions and controversies.

The increase of number of enrolled students does not implement the inclusion policy. The students frequently end up neglected and isolated, for a number of reasons, from barriers faced in the route between their homes and the school to the formation of teachers. The constraints are physical, systemic and attitudinal. This contributes to the permanence of a situation of segregation, which is reflected in the development of the disabled student and hampers the exchange of experience between them, their colleagues and their teachers.

The inclusion defended by Sassaki (1997) requires reciprocity between society and the disabled individual.
The respect and appreciation of student's diversity require that the school defines its responsibility in providing inclusive common spaces and encouraging the production of materials and techniques for these students.

In Brazil, the laws concerning the inclusion of impaired students are one of the most complete in comparison with the laws of other countries, however regarding the teaching of Geography, maps and graphics created for visually impaired students are scarce and the existing ones are not used with the desirable frequency, contributing for a low performance of this group of students.

The absence of such resources at school is due to the lack of specialized production, unpreparedness of teachers in using the materials (CARMO, 2009), time and cost of production, lack of equipment and appropriated machines used in the reproduction of the materials, low financial incentive in research and even the need to cartographical initiation (when the student first starts using a map).

In 2008, the Secretariat of Education of the State of São Paulo (Secretaria da Educação do Estado de São Pau-lo) launched a curricular proposal to be immediately implemented in all public schools in the state. The current curriculum adopts the use of a didactic material with a minimum content per subject. Entitled "São Paulo Faz Escola", the material is composed by the Caderno do Aluno (Student's book) and the Caderno do Professor (Teacher's Edi-tionTextbook) for each discipline. The Caderno do Aluno contains mainly exercises to be solved 
in class or at home. The Carderno do Professor offers methodological suggestions to the teachers.

Although the inclusion policy seeks a global access to Education, it encompasses specific needs for public schools. For that reason, the government offers braille and enlarged versions of the didactical material.

Against this backdrop, Tactile Cartography contributes with learning by being a subject destined to the teaching of Geography to visually impaired people. It can transform the traditional manner of learning and teaching of Geography.

In order to expand the discussion about this theme, the Caderno do Aluno vol. 2 for the sixth grade was analyzed in its two versions destined to the public with special needs: braille and enlarged. This particular book was chosen, since it presents to students the basic concepts of the cartographical language, which are fundamental to build conscious readers of maps.

By evaluating the potential of the distributed adapted books, we will present an alternative proposal of adaptation based on the principles of the Tactile Cartography associated with braille, with the purpose of comparing the results achieved by its use in the classroom and the results achieved by the use of the books offered by the government.

\section{Communication and tactile graphic representation of the geographical space}

Geography, as a school discipline, plays an important role in the formation of citizens, since its main object of study is the geographical space. It is through Geography that students can think critically about the world and their part in the face of spatial phenomena. More than understanding, students must feel that they construct Geography at every moment (CAVALCANTI, 1999). This should be the main concern of maps developers: make it able to guide the user through the information available allowing them to construct the Geography learning, in other words, to prepare them to transform information into knowledge.

For this purpose, Geography makes use of images that not only are able to represent the everyday life, but also different spaces and situations which would not be possible to be represented without graphical resources. Further-more, Geography handles various abstract themes, such as Earth movements, geographical coordinates, imaginary lines, etc. How would that be possible using only a text?

By working with topics related to society, such as the transformation of space, which reflects the technological advances, it becomes necessary to constantly revisit literature and to propose new ways of following social changes. For that, many researches that study specific social groups were developed, for example Tactile Cartography and Social Cartography.

Although the cartographical Science advances are expressive, maps used in elementary school are mostly under-stood as illustrations. They become static and lifeless images (MORAES, 2008).
Not only are tactile maps used in the teaching of Geography to visually impaired and low sighted students, but also contribute to the learning of all students, no matter if they have any kind of disability. Those maps can also promote educational and social inclusion, as well as the exchange of experiences among classmates and teachers (SENA, 2008; CARMO, 2009) and social guidance and mobility (considering studies in the field of inclusive tour-ism) (CATELLI, 2011). Maps can be source of research to designers, engineers and artists, as well as a great contribution to the autonomy of impaired individuals, especially concerning guiding and mobility. Tactile Cartography al-lows cartographical elements to be selected and placed on the map for a better representation of the studied phenomenon and the coordinates can be excluded in order to avoid pollution of information, for example. Therefore, the most important aspect to take into account is to assure that the message and information are communicated, even though some sort of cartographical "sacrileges" become necessary.

\subsection{The importance of the haptic system}

The main reason why the sight is the study object of this research is its importance to human beings. It is responsible for the space delimitation through time. Together with hearing, sight is a sense of distance, which enables people to deal with information extern to the body (MASINI, 2013).

The deficiency or the compromise of sight can bring direct consequences to the development and learning of an individual. His guiding, mobility and world knowledge, therefore his independence, will be acquired through the other senses. Thus it is necessary that they are stimulated in a way that they can allow autonomy to the impaired per-son. Ochaita and Rosa (1995) mention the need of a teaching that communicates, by alternative means, the information that cannot be obtained through the eyes." (p.183) ${ }^{1}$.

According to a 2012 report from the World Health Organization, there were 285 million visually impaired people in the world: 39 million suffering from blindness and 246 million low sighted. Gilbert and Foster (2001, p.53) estimated the existence of approximately 1.4 million blind children in the world and most of them come from developing countries. This concentration is due to the poor nutrition, the proliferation of diseases, shortage of doctors, specialists, hospitals and treatments, which increase considerably the number of acquired blindness cases.

When we mention visual impairment, we are referring to the compromising of light perception and of something that reflects light. We also mention the eye that processes image projected by electrical impulses and lastly a brain that receives and give meaning to these impulses (SMITH, 2008, p.331). Those can vary in intensity, nature and time when they have first occurred. Under the

\footnotetext{
1 “ensino que transmita, por vias alternativas, a informação que não pode ser obtida através dos olhos."
} 
title of visual deficiency there are a large number of disorders involved.

The sight mechanism results from the interaction of several visual functions: visual accuracy, visual field (standardized and quantitative measures), binocular coordination, sensitivity (or lack of it) to contrast and luminosity and color sight. In order to better understand the condition of a visually impaired person, it is important to observe the moment when the sight began to fade.

Manipulating different objects, textures, sizes and shapes stimulates de cerebral activity and allows the perception of yourself and what surrounds you. According to Kastrup (2007), the sense of touching can be considered the most appropriated sense to give spatial reference and dislocation to visually impaired people. Therefore it is through it that the spatial perception should be reconstituted.

The learning process through touch is different. While sight synthesizes the visualized elements, touch builds the representation sequentially, for the perception field is more restrict. Considering learning through tactile materials, the sense of touching is exclusively dependent on the hands. The work memory - the one used in a short-term comprehension - is filled with information touched in parts. By touching it is also possible to apprehend non-visible in-formation, such as temperature.

Although little is known about representation through touch, it is still the most viable kind of representation to use in classrooms of public schools. Tactile Cartography is attractive, because it allies different types of materials, promoting meaningful group work between teachers and students, both impaired and non-impaired. Researchers, teachers and psychologists must work in partnership with visually impaired students.

\section{Analysis of the Caderno do Aluno}

The adapted books available to visually impaired students at public schools in São Paulo are made through con-tract between the government and Foundation Dorina Norwill, an institution specialized in the confection and adaptation of materials to visually impaired in Brazil over 60 years.

A serious issue to be considered when analyzing the material is the fact that there was no dialog between the authors of the maps and the professional responsible for the adaptation. Therefore the adaptation became a true copy of the printed material without the necessary alterations for the specificities of the visual impaired student.

The braille version is frequently divided in more than one book, since this technique uses a bigger space and the sheets of paper are thicker (Image 1). This model presents not only the text but also the pictures adapted to braille. Although Foundation Dorina Norwill can use the technology that allies braille to paint, the contract with the Government establishes that two different versions of books must be used.

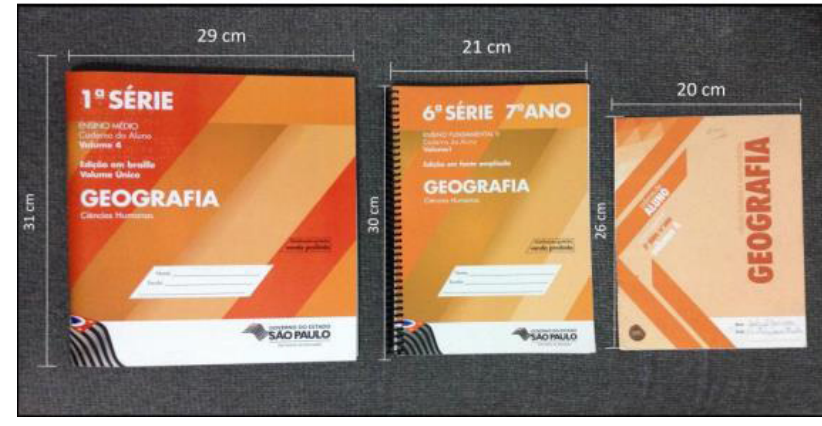

Image 1: Dimensions of the three versions of Caderno do Aluno. From left to right: braille version, enlarged version and regular version, Source: Personal File

Another issue concerns the fact that the braille printerused in the adaptation of the whole content of the book, images and text - lack a great variety of dots, lines and marks, which makes unviable to work with students the different sorts of information contained in the same image.

During the analysis we faced a bigger issue, which exceeds problems with adaptation: the delay in the delivery of the adapted materials is linked to logistics in the distribution of books by the Secretariat of Education. The books take to 4 months to arrive at the schools.

Considered fundamental pieces of the inclusion process, the teachers were asked to talk about their relation with Cartography in regular books, the adapted version of the books and Tactile Cartography. 32 teachers participated in the survey, which contained both multiple choice and open questions, available through Google Docs ${ }^{\circledR}$ and announced on the social network Facebook ${ }^{\circledR}$. Some of the answers mentioned the difficulty in teaching Cartography, the lack of knowledge about its tactile modality, scarce contact with the adapted books, the need of training, lack of available time and materials.

In addition, in order to analyze the books, teachers and students with different grade levels and formation participated on the research. The analysis was divided in two steps: the technical evaluation of the materials, which be-came the basis to the construction of an alternative tactile material, and the use of this alternative material in class. Two teachers and two students from the Associação dos Deficientes Visuais de Ribeirão Preto e Região (ADEVIRP - Visually Impaired Association of Ribeirão Preto), as well as graduation and post-graduation students from the course of Educação Especial (Special Education) of the Universidade Federal de São Carlos and a Geography professor from Instituto Benjamin Constant (IBC) contributed to the analysis while we were participating on scientific events in Brazil.

As examples, pictures 3 and 4 show an enlarged and a braille map, respectively. 


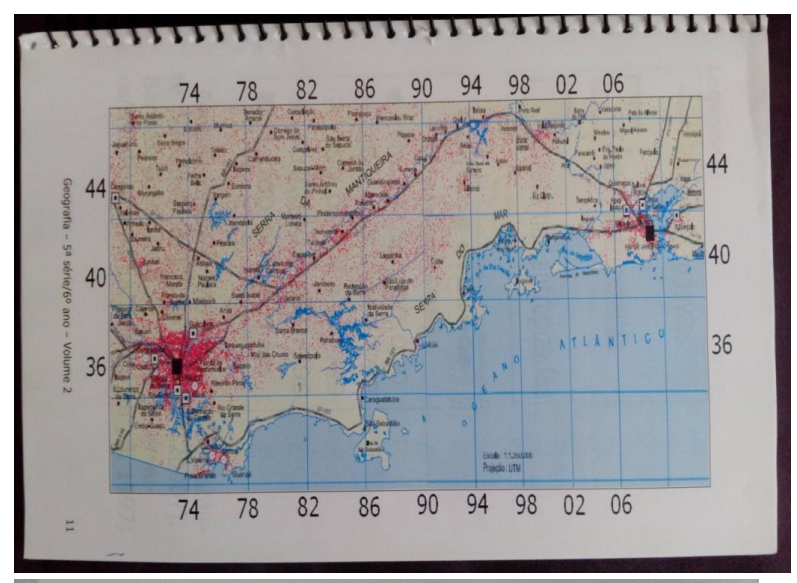

Pictures 2 and 3: Maps from page 7 of the Caderno do Aluno, 6th grade, vol.2, 2013, in both enlarged and braille versions. Source: Personal File.

The main topics discussed during the presentations and analysis of the adapted materials distributed by the Secretariat of Education of the State of São Paulo were:

- The enlarged maps have low resolution and dead pixels, making the reading difficult;

- Some maps were not properly enlarged: some pages have a lot of white space on them and others do not bring the map;

The enlargement did not respect the scale of the maps;

- Enlarged and braille maps are presented in the same size of maps in the regular version of the book;

- Teachers become intimidated by not knowing braille;

- The adapted books do not stimulate group work;

- Most teachers do not know the proper methodology to use in class with a visually impaired student;

- Braille images are considered tedious and tiring to touch;

- Some exercises are not presented in the braille;

- Few interviewees do not know Tactile Cartography;

- The pages of the adapted books do not match the pages of the regular books.
Listening to the people responsible for the inclusion of visually impaired students became an important part of the process of designing and production of alternative materials that were both accessible and stimulating for students and teachers, changing the traditional teaching of Geography.

\subsection{A different proposal of adaptation}

According to Bertin (1977), a map can contain up to eight visual variables: two plan dimensions ( $\mathrm{X}$ and $\mathrm{Y}$ ) and six third dimension variables $(Z)$, which are size, value, granulation, color, orientation and shape. Each one can transcribe a component of information. Graphical language must allow transcription of relations of similarity/difference, sequence or proportion between objects. These relations consist of meanings of graphical representation, which are expressed by visual variables and can be converted in tactile mode. In dimension $\mathrm{Z}$, volume and texture are inserted seeking the tactile comprehension of the user.

The preference to Bertin's variables is due to their predisposition to be easily adapted to the haptic system. The same does not occur with different branches of graphical semiology.

We searched for a material that could be able to help in the inclusion process of the students. We stressed the use of colors even for maps used by blind students, since it would facilitate the use of the map when working with a teacher, classmates or family members who do not have any impairment.

In order to handle the excess of information presented in a tactile map can and avoid "tactile pollution", it is important to use a collection of maps instead of only one. This collection must maintain the base-language (projection, north and scale, if necessary), but the different maps are supposed to be used separately. Those maps must bring the same location of the elements used in the other maps (title and legend, if necessary) and the same symbols.

Other principles that should be followed for a better use and understanding of the maps are:

- the use of capital letters should be avoided, since they demand more space in the braille system and an enlarged font;

- $\quad$ words must be represented horizontally avoiding any possible disturbance;

- legends can assist the understanding and some representations can be enlarged or reduced when adapted;

- different textures, shapes and colors (for low sighted students) can facilitate the assimilation of the content;

- there must be enough space between the represented signs (eventually it is preferable to zoom the represented area.

The quantity of textures and colors must also be taken into consideration (JORDÃO e SENA, 2011). According to the surveys, 5 variables would be enough. 
Edman (1992) defends that the distance between symbols should not be less than $3 \mathrm{~mm}$, which is the approximate distance between two braille cells. The symbols must fit the tip of the fingers, but be large enough to be found and identified.

However, one of the most important aspects of the process of adaptation is the feedback given by the users. These feedbacks must guide the decisions that will be made during the adaptation, so that the maps become effective. Nevertheless, this fact is both relevant and difficult, since it is connected to the individual characteristics of each user. However they should be taken into consideration.

For our proposal of adaptation, we selected images from the Caderno do Aluno used until 2013. The selected materials for adaptation were accessible and heatresistant. Those types of materials are vital, since the main objective is to produce base-maps which can be copied in acetate or PVC in the Thermoform machine. That way, their cost is low, the durability is high and the process of production is relatively simple.

We have opted for standardize the materials used for a specific information. For instance, if we use a corrugated yellow cardboard to represent the sun in one map, the sun will be represented with the same material in every map in which the information "sun" appears. Obviously that does not mean the material cannot be substituted. The main purpose is to facilitate the reading of the information by the recognition of the same texture and color.

The bases were fabricated in a white paperboard with three different sizes: $30 \times 22 \mathrm{~cm}, 35 \times 22 \mathrm{~cm}$ and $40 \times 33$ $\mathrm{cm}$, since they improve reading and are easy to be transported. We stress that it was important to prepare a material that was easy to be transported and would not compromise the apprehension of information through tact. According to Almeida (2007), the boards should not exceed $50 \mathrm{~cm}$, once the field of touch is more restrict than the field of vision. In most of the representations we use redundancy. That is to say that we use two variables to represent one information. For example, texture and color.

The pagination is also important and it was organized as following: the map will receive the same number of the page of the original book preceded of the letter $\mathrm{P}$. That is to say that if the map in the original book is on page 1, the correspondent tactile map will be numbered P.1. If on page 1 of the original book there are two maps, the first tac-tile map will be numbered P.1A and the second will be numbered P.1B. In case one map has to be divided into two in the tactile version, the maps will be numbered $\mathrm{P} 1 \mathrm{~A}$ and P1A2.

The level of generalization was guided by Almeida (2007), since the tactile perception is not global, the visually impaired must bring pieces of information together, in order to form a whole image.

This methodology was adopted to facilitate the identification of images during classes, since we faced a difficulty with the books distributed by the government: the number of pages of the adapted books was not related to the original books.

It is important to keep in mind that in a tactile map, as well in a conventional map, the basic notions of Cartography, such as scale, projection, proportion, location and orientation, must be clear to the user and should be introduced when needed, not as an obligation, which can interfere in the apprehension of information taught $^{2}$.

As an attempt to minimize these barriers, we produced 22 maps, which can be time-consuming and demands great knowledge of Tactile Cartography. Besides the maps are not a long-lasting material, due to the transportation and handling. All maps had to be retouched during the tests and evaluations. The ideal is that those adapted maps could serve as a mold for transparent copies in Thermoform, which enables the insertion of an enlarged graphic version below it with the same dimensions, combined with braille and revised enlarged exercises. This material should be distributed by the Government.

The picture below shows blind and low sighted students evaluating the adapted materials.

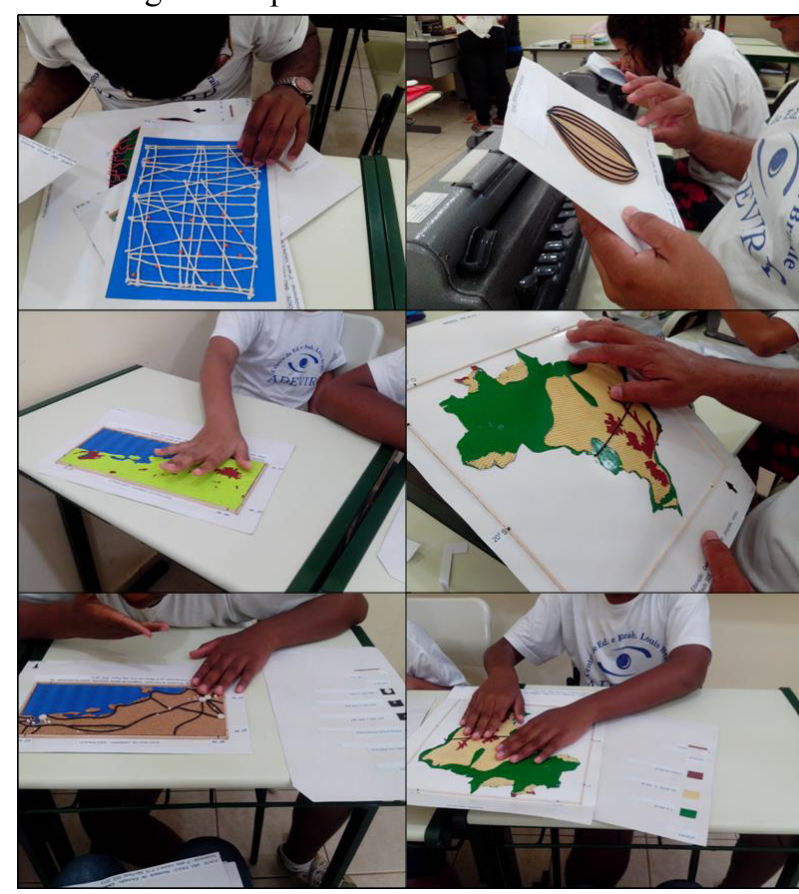

Image 4: Evaluation of the maps and exercises by visually impaired students

During the first years of school life, visually impaired students often make use of different shapes and textures to become stimulated and the production of books with such characteristics is quite common. However, during the last grades, multi-sensory materials are not frequently used and learning becomes more and more restricted to oral descriptions. Through the material produced during this research, which followed the principles of Tactile

2 As it is something complex and specific, the situation explained above has originated a tutorial available in the link: $\quad$ https://drive.google.com/file/d/0B-5Z1Tz3fCRNFBPT0toQ1Qza0E/view 
Cartography, it was possible to notice improvement in the learning process. The material also stimulates group work. We believe that the appropriation of the cartographical language must promote interactive and individual learning, but should focus specially in the interaction between parents, teachers, students and the academic community.

More than merely checking the acquisition of contents, teaching seeks the construction of knowledge through the interaction of individuals. Appropriate materials and means are important tools during this process.

In order to develop graphical representation, it is vital to understand the maps language. By constructing the materials, it became necessary to select the way, in which to communicate with users of maps. Therefore it is necessary to revisit cartographical concepts explained previously by teachers. As a result, students expand the cognitive capacity of communication by images, which is a fundamental part for a better interaction with maps and other tac-tile representations available in public spaces for guiding and mobility.

To validate this process, we adopted a methodology that could contemplate both observations of practices in the classroom and listening to teachers and students.

In view of the current situation of Education in the State of São Paulo and lack of expectations of change in that scenario, this research tried to show some possibilities of adaptation that can understand the most urgent needs of students and Education. With some investment, tactile materials could be produced on a large scale and with an acceptable durability, taking issues like transportation, distribution and handling into account. For that to happen, we need willingness from the government, exchange of information between research institutions and further discussions on the process of standardization of tactile maps.

\section{References}

Almeida, R. A. (2007). A Cartografia Tátil no Ensino de Geografia: teoria e prática. In: Almeida, R.D. (ORG.) Cartografia Escolar, Editora Contexto, São Paulo, 2007.

Almeida, R.A.de. Tactile Maps in Geography. (2015). In: Wright, J. D. (org.), International Encyclopedia of the Social \& Behavioral Sciences, $2^{\mathrm{a}}$ edição, Vol 24. Oxford: Elsevier. pp. 9-13.

Bertin, J. (1977). .La Graphique et le Traitment Graphique de l'Information. França: Flamarion, p.277.

Carmo, W. R. (2009). Cartografia tátil escolar: experiências com a Construção de materiais didáticos e com a formação continuada de professores. Dissertação (Mestrado em geografia) - USP - Faculdade de Filosofia, Letras e Ciências Humanas. São Paulo. SP.

Catelli, M. R. (2011). Cartografia tátil e turismo inclusivo: o início de um desafio nas estâncias turísticas de Barra Bonita e Igaraçu do Tietê-SP . VII Colóqui de Cartografia para Crianças e Escolares. Vitória/ES.

Cavalcante, L. de S. (1999). Propostas curriculares de Geografia no ensino: algumas referências de análise. In:
As transformações no mundo da educação. Geografia, ensino e responsabilidade social. São Paulo: AGB Terra Livre, $\mathrm{n}^{\mathrm{o}}$. 14, p.11-21.

Edman, P. K. (1992). Tactile Graphics. American Founation for the Blind. New York.1992.

Gilbert, C.; Foster, A. (2001) Chidhood blindness in the context of vision 2020: the right to sight. Bulletin of the World Health Organi-zation,v. 79, n.3, p. 227-232.

Jordão, B. G. F., Sena, C. C. R. G. (2011). Cartografia Tátil para estudantes deficientes visuais: a experiência do globo adaptado. Anais do evento: Encontro Nacional de Práticas e Ensino de Geografia. Goiânia,

Kastrup, V (2007).. A invenção na ponta dos dedos: a reversão da atenção em pessoas com deficiência visual. Psicologia em Revista, Belo Horizonte, v. 13, n. 1, p. 69-90.

Masini, E. A. F. S. (2013). O perceber de quem está na escola sem dispor da visão. 1. ed. São Paulo: Cortez.

Ochaita, E.; Rosa, A. (1995). Percepção, ação e conhecimento nas crianças cegas. In: Coll, C., Palácio, J.\& Marchesi, A. (Orgs.). Desenvolvimento psicológico e educação. Porto Alegre : Artes Médicas,. v.3, cap.12, p.183-197.

Sassaki, R. K.. (1997). Inclusão: construindo uma sociedade para todos. Rio de Janeiro: WVA.

Sena, C. C. R. G. (2008) Cartografia tátil no ensino de Geografia: uma proposta metodológica de desenvolvimento e associação de recursos didáticos adaptados a pessoas com deficiência visual. Tese de Doutorado. Departamento de Geografia, FFLCH - USP. São Paulo.

Smith, D. D. (2008) Introdução à Educação Especial: Ensinar em tempos de inclusão. São Paulo: Artmed. Tradução M.A. Almeida.

Vasconcellos R. (1993). Cartografia Tátil. Revistas Ciência Hoje e Ciência das Crianças, São Paulo - SP.

Ventorini, S. E.(2009). A Experiência como fator determinante na representação espacial do deficiente visual. São Paulo: UNESP. 